\title{
COMMITTEES, POLITICS, SCHOLARSHIP AND LAW REFORM: ANTITRUST STUDIES IN PERSPECTIVE
}

\section{Louis B. Schwartz $\dagger$}

The Attorney General's National Committee To Study the Antitrust Laws is the latest of a long series of official investigations of business organization and control. Among the outstanding studies in this series were those of the Temporary National Economic Commission (1938-1940), The Pecora Investigation of Banking (1933), The Monetary Commission (1912), The Armstrong Investigation of the Insurance Business (1905), The Industrial Commission (1898). ${ }^{1}$ Inevitably the work of Attorney General Brownell's Committee invites comparison with these earlier enterprises, particularly the T. N. E. C. of the Roosevelt administration. It is the purpose of this essay to make that comparison. From that comparison emerges the conclusion of this essay, namely, that the organization, working methods and results of our Committee were largely determined by the political atmosphere in which the Committee was conceived and functioned. In that atmosphere the Committee was bound to recommend, as in my opinion it did, a retreat in antitrust law and administration.

\section{Contrasts in the Statement of the Question To Be Investigated}

Both the T. N. E. C. and the Brownell Committee started with a hypothesis dictated by the political situation. The hypothesis of the Roosevelt administration was that the ills of the Great Depression were due to monopolistic practices, the greed and poor judgment of those shadowy figures in "Wall Street" who dominated and regulated the economy. ${ }^{2}$ Particularly after the fiasco of the effort to solve the depression by putting governmental sanction behind industry selfregulation, under the National Industrial Recovery Act, it became necessary to try a new tack, to explore the potentialities of free com-

$\doteqdot$ Professor of Law, University of Pennsylvania Law School. Member, Attorney General's National Committee To Study the Antitrust Laws.

1. See the excellent summary of these and other investigations in LYNCH, THE CONCENTRATION OF ECONOMIC POWER 387-94 (1946).

2. See the chapter on "Creation of the T.N.E.C." in LYNCE, op. cit. supra note 1, especially at $17-25$ and 364 . 
petition as the best check against business abuse and the surest incentive to industrial progress. The basic question that will be raised about the antitrust laws in such an atmosphere is: "Do they need strengthening? Have we gone far enough to put effective controls on business?" The hypothesis of the Eisenhower administration was inevitably quite different. In one of those recurrent swings of national political psychology, the onus of distrust had shifted; the electorate of this later era saw the current evils as war and communism, not unemployment, farm distress or business stagnation. War and communism can be blamed on the "politicians" in power, regardless of party. A booming economy boosts the prestige of businessmen. It was avowedly a businesslike, if not a businessmen's, administration that President Eisenhower was to lead. In such an administration, the basic questions that will be raised about the antitrust laws must be: "Have they gone too far? Do they unduly limit the freedom of the now trusted leaders of business?"

It is true that President Eisenhower expressed the hope that the Attorney General's National Committee would

". . . prepare the way for modernizing and strengthening our laws to preserve American free enterprise against monopoly and unfair competition." 3

It could hardly have been otherwise. Antitrust has become such a sacred cow of American political tradition that all proposed changes must present themselves as "strengthening." 4 In this country one must go back to an unashamed aristocrat like Holmes for a frank disavowal of the philosophy of the Sherman Act. ${ }^{5}$ I do not recall in the debates of the Attorney General's Committee a single expression of hostility to antitrust as a concept, despite the fact that the overwhelming majority of its recommendations did favor defendants. It all turns on what one regards as "strengthening." Ingenious and conscientious men can, as the Report does, find it possible to "strengthen" the antitrust laws by reducing the amount of damages

3. Report of the Attorney General's National Committee To Study The ANTITRUST LawS iv (1955) (hereinafter cited as REPORT).

4. Cf. Thurman Arnold's conception of the Sherman Act as a kind of official religion to which we all make obeisance without allowing it to interfere in the practical affairs of life. ARNOLD, The Folriore of CAPITALISM 207-30 (1937).

5. "Between ourselves, I deeply regretted the situation of the Steel Trust Casedecided 4 to 3 -without a majority of the whole court and with the probability that if the whole court could sit it would have gone the other way. I could not change my opinion out of deference to that fact, but I have been in a minority of one as to the proper administration of the Sherman Act. I hope and believe that I am not influenced by my opinion that it is a foolish law. I have little doubt that the country likes it and I always say, as you know, that if my fellow citizens want to go to Hell I will help them." 1 Holmes-LaskI LetTers 248-49 (Howe ed. 1953). 
recoverable by the victims of a conspiracy to violate those laws, or by expanding defenses and justifications for price discrimination. I have not the slightest intention of impugning the good faith of such proposals, least of all that of the President, who could have no notion how the Committee would implement his call to "strengthen" the antitrust laws. Just as the New Dealers could honestly say that they were not "anti-business," but on the contrary were promoting the longrange interest of private enterprise with legislation like the National Labor Relations Act, the Securities Act, the Public Utility Holding Company Act, and the Fair Labor Standards Act-and who can say that events have not confirmed their forecast?-so it is permissible to think of measures which appear to be unfavorable to the prosecution as nevertheless promoting the central purposes of antitrust in the long run. ${ }^{6}$

In the era immediately preceding the organization of the Committee, the preeminent statement of the conservative hypothesis was that of Professor S. Chesterfield Oppenheim in his Michigan Law Review article entitled "Federal Antitrust Legislation: Guideposts to a Revised National Antitrust Policy." 7 It was preeminent because of Professor Oppenheim's reputation and wide experience, his disinterestedness, and especially because the theme which it sounded with renewed vigor was traditional and honored. For half a century it had expressed and inspired resistance to the harsh imperatives of antitrust. That theme is the "Rule of Reason." It was inevitable that Professor Oppenheim should be given major responsibilities in the Attorney General's Committee.

To repeat, then, both the Roosevelt and the Eisenhower administrations approached the task of appraising the antitrust laws with a predisposition, a hypothesis; and the hypotheses were opposing ones, in each case dictated by political background. There is of course nothing wrong with having a hypothesis for investigation; an investigation is likely to be aimless if it doesn't have one. The fact that both investigations tended to confirm the predisposition of the investigators may cause one to raise a skeptical eyebrow, but it would be quite irrational to reject both merely on this ground. One must inquire as to the technique of investigation employed in each case. The validity of a scientific conclusion rests largely on the validity of the method by which it is reached. We return therefore to a contrast of the

6. President Roosevelt's message calling for the T.N.E.C. disavowed hostility to business and described itself as a "program to preserve private enterprise." See LYNCH, op. cit. sipra note 1 , at 25 .

7. 50 MTCH. L. REV. 1139 (1952). 
organization and method of the Attorney General's National Committee with other available methods of reviewing the antitrust laws.

\section{Contrasts in Committee Organization; REPRESENTATIVENESS; EXPERTISE}

There are many ways to study the antitrust laws and a variety of bodies to which such a study might be entrusted. Individual scholars in law and economics may write treatises or articles upon their own responsibility. Studies may be carried out under sponsorship of private organizations, ${ }^{8}$ some disinterested, others with obvious predispositions. The executive branch of the Government engages in studies of the efficacy of the laws which it has a duty to enforce, as in the publications of the Federal Trade Commission on mergers, resale price maintenance, and marketing restraints in various fields of business. In addition, in recent years, the Department of Commerce has given voice to the views of Business Advisory Committees in calling for reexamination of the antitrust laws, especially with a view to eliminating "uncertainty" which is said to impede legitimate business activity particularly in international trade." Bar associations have, of course, been active in this field. ${ }^{10}$ The American Law Institute has explored the possibility of putting antitrust on its agenda. The most continuous and well financed activity has been that of the congressional committees. Year after year, they review the work of the government agencies, hear complaints of small businessmen, conduct investigations of practices and structure of big business, and stage public hearings at which representatives of all points of view contribute their testimony to the building of enormous printed records.

No one would suggest that the task of appraising and revising antitrust law and policy should be delegated to a single scholar, however

8. E.g., The Twentieth Century Fund's Survey of International Cartels and Domestic Monopoly (Stocking \& Watkins, research directors) with a report and recommendations by a committee consisting of James M. Landis, formerly Chairman, Civil Aeronautics Board, Dean, Harvard Law School, Chairman, Securities and Exchange Commission; A. S. Goss, Master, The National Grange; Marion Hedges, Special Assistant to the Labor Advisers, Economic Cooperation Administration, formerly Director of Research, International Brotherhood of Electrical Workers; Donald M. Nelson, Chairman, Electronized Chemicals Corp., formerly Chairman, War Production Board; Frank M. Surface, Consultant to Management, Standard Oil Co. (New Jersey); Jacob Viner, Professor of Economics, Princeton University; and J. Raymond Walsh, Director at Large, National Bureau of Economic Research, formerly Director of Research and Education, Congress of Industrial Organizations. Publications included three volumes: Monopoly AND FreE ENTERPRISE (1951), Cartels or Competition? (1948), Cartels in Action (1946) ; Cf. NaT'l Ass'N of Manufacturers, The American Individual Enterprise System (1946).

9. See Business Advisory Councit, Report to the Secretary of Commerce oN EfFective Competitron (1952), summarized in 21 U.S.L. WeEK 1044 (Dec. 23, 1952).

10. See, e.g., A.B.A. Section on Anttrtust Law, Report of the Commtimee on Practice and Procedure in the Trial of Antitrust Cases (1954). 
learned and eminent, or even to a team of scholars with technical assistants, despite the fact that this is the typical study organization in physics, biology or medicine. It is important to understand why mere scholarship or expertise is not enough in dealing with problems like antitrust. The reason is that goals, values, faith and similar intangibles must play a large part in formulating antitrust policy. If this were not true, there could hardly be such disagreement on the subject among men of equal professional competence in law and economics as one finds today. If the task had been merely to restate the present law, expertise, as represented by a small group of lawyers, could have done the job well enough. The Attorney General needed no committee of 61 lawyers, economists and professors for that purpose. Any such restatement would, like the Committee's Report, have to indicate that some applications of the law remain uncertain. The Committee $R e$ port does not reduce the areas of uncertainty in antitrust precisely because whenever it speaks positively on a controversial topic, it is most clearly expressing policy preferences rather than restating what is already the law.

Much could be said in favor of the proposition that a new administration should restudy the antitrust laws through its own personnel, perhaps an interdepartmental committee. It is noteworthy that the Roosevelt administration at first favored this course and that the issue of executive versus legislative control was sharply drawn in the maneuvers that preceded congressional authorization of the T. N. E. C. on a basis of equal representation for Congress and the Executive. ${ }^{11}$ Powerful figures like William O. Douglas (S.E.C.), Thurman W. Arnold (Dep't of Justice), Herman Oliphant (Dep't of Treasury), firmly in control of newly recruited, enthusiastically pro-administration bureaucracies, were eager to serve on the T.N.E.C. It is understandable, therefore, that President Roosevelt, reasonably sure of congressional support in any event, was ready to assume full executive responsibility for the investigation. The problem of the Eisenhower administration was quite different. One difficulty here would be that the people engaged in the study would be pretty much those who had administered the antitrust laws under the Democrats, for there had been no wholesale replacement of second level civil servants in either the Federal Trade Commission or the Department of Justice. ${ }^{12}$ Another difficulty lay in the lack of effective Republican

11. See LYNCH, op. cit. supra note 1 , at $28-31$.

12. Cf. charge by Richard W. Slocum, President of the American Newspaper Publishers Ass'n that "Attorney General and Barnes Follow Will of Underlings" in filing an antitrust suit against the association. N.Y. Times, May 11, 1955, p. 20, col. 5. 
control of Congress. Congressional acquiescence in reform of the antitrust laws could hardly be expected if the proposals presented themselves as partisan legislation. Nor would the backing of Business Advisory Committees or antitrust sections of bar associations improve the political reception of reform proposals. But the most likely explanation of all for the administration's preference for an outside agency to formulate its policy on antitrust is that it genuinely desired independent guidance-the more so because within the numbers of its own top officialdom, conflicting tendencies could be felt, ranging from the vigorous trust-busting inclinations of Assistant Attorney General Barnes, new head of the Antitrust Division, to forthright identification of national interest with big company interest in some purlieus of the Department of Defense and the National Security Council.

For reasons already noted, the administration could not use congressional committees to carry out its antitrust inquiry, despite some obvious advantages of that method, e.g., tepresentative and politically responsible character of these bodies, subpoena power to compel testimony, permanent staff, funds to retain consultants. Not only was party control of Congress, and therefore of the committees, liable to be upset, but there was no tradition of committee investigation of excesses of antitrust enforcement, which, as I have said, was the hypothesis to be explored. In the political climate of this country conservative administrations are driven to quiet deemphasis of antitrust rather than public hearings avowedly looking towards modification. An investigation of that kind would hardly be likely to enlist popular enthusiasm or to advance the political prospects of the participating Congressmen. It was plainly impossible for the administration to ask Congress for authority and funds to investigate the antitrust laws, because the public would never believe that this administration would be investigating anything but ways of tempering those laws. Debates on any resolution to authorize the study, as well as the open hearings which Congress would almost certainly have required, would have been turned to political advantage by the Democrats. Congressional support would have meant participation in the study by selected legislators of both parties, with real danger that the pressure from the minority would precipitate investigations into the structure and practices of dominant industrial firms. Inevitably, the study became a purely executive enterprise, with limited financing by the Antitrust Division out of its regular enforcement budget. No senators or representatives served on the Brownell Committee.

In contrast, the Temporary National Economic Committee consisted of six legislators and six representatives of the executive depart- 
ment. $^{13}$ Senator O'Mahoney, sponsor of the resolution authorizing the investigation, became its chairman. Congress appropriated over $\$ 1,000,000$ to the work of the committee.

Lacking congressional collaboration or administrative officials with the prestige and experience of the leading New Dealers who served on T. N. E. C., the Eisenhower administration nevertheless required an investigating body whose recommendations would carry weight with Congress, the courts and the administrative agencies. The composition of the Brownell Committee was designed to meet this need by its impressive number (61), by being composed almost entirely of "experts," and by including, at least in the originally announced list of inyited members, such respect-compelling personages as former Supreme Court Justice Owen J. Roberts and Bernard Baruch. ${ }^{14}$

The body had to be reasonably representative, else it would have no more political weight than the bar association and business advisory groups that had long and vainly sought amelioration of the law. At the same time its composition must give reasonable assurance that the conservative hypothesis about the antitrust laws would be the one explored. A reasonable amount of control had to be maintained by the Attorney General since he had instigated the study and was paying for it; but on the other hand the administration had to be insulated from automatic responsibility for the proposals that the Committee might put forth. Moreover, the concept of independent expertise required at least a sharing of directorial responsibility by a scholar. The Co-Chairmanship of Assistant Attorney General Barnes and Professor S. Chesterfield Oppenheim admirably served these purposes. Also, by making it clear that the Committee was advisory only, the Attorney General guarded himself and the administration against commitment to recommendations which might be either embarrassingly conservative, excessively aggressive, or politically dangerous. The Department of Justice has, in fact, never made clear how much of the Report is administration policy. ${ }^{15}$

13. Cf. earlier investigations: The Industrial Commission (1898) (5 senators, 5 representatives, 9 from civil life); The Monetary Commission (1912) (9 senators, 9 representatives); The Pujo Committee (1913) (House committee of 11). LyNCF, op. cit. supra note 1 , at $387-90$.

14. These distinguished men subsequently proved to be unavailable and did not actually become members.

15. In accepting the Report, the Attorney General said: "Only after careful study, will we be able to determine which of its legislative recommendations shall be recommended as administration policy to the Congress and which of its administrative recommendations shall be adopted." On the other hand, he ventured to predict that "... it will have a heavy impact in strengthening our antitrust laws and clarifying our enforcement policies." Dep't of Justice Release, March 31, 1955. But see note 31 infra. 
The representative character of the Brownell Committee has been sharply questioned by some newspaper columnists and by members of antitrust and small business committees of Congress, principally because of the identification of many of the group as counsel for large corporations, in some cases even in pending suits involving issues on which the Report speaks. ${ }^{16}$ As to this I can say that, assuming antitrust expertness, as well as general integrity, was to be the criterion of selection, there was a fair representation of experts who strongly favored antitrust; that is to say, if all the available "experts" on antitrust were classified into two groups, the strongly favorable and the moderates (there are no "anti's," as previously noted), the former group probably had the larger delegation in proportion to total numbers. With selection in the hands of men like Judge Barnes and Professor Oppenheim, this was bound to be the case, not only because of their own integrity, but because they recognized as an intellectual matter that proposals formulated without the benefit of the fullest criticism from these sources would be the poorer for that reason. Moreover, the debates in Committee never impressed me as advocacy of clients' positions. It was not unusual to hear men whose private interests would point in conservative directions argue powerfully for a strong antitrust position on particular issues. Nevertheless it remains true that the professional experience of a major proportion of the members was gained in representing defendants. This fact became crucial in connection with the decision that the Committee, unlike T. N. E. C., would use "collective experience" rather than fact finding as the basis for its recommendations. ${ }^{17}$ It is easy to see how these men, summoned from the heat of battle against Federal Trade Commission and Antitrust Division and relying on their "collective experience," might in all honesty have a very special view of what was wrong with the antitrust laws.

But the main vice in the composition of the Attorney General's Committee was the very principle of selection based exclusively on "expertise." This rested on the assumption that legal technicians are as qualified to produce an antitrust policy as they are to engage in antitrust litigation or counseling. This is not true. Technicians are useful in telling us how to accomplish our purposes, or what difficulties must be faced in seeking a certain goal. Policy, on the other

16. See the testimony of Congressman Patman in Hearings Before the Subcontmittee on Antitrust Law of the House Committee on the Judiciary, 84th Cong., 1st Sess., ser. 3, pt. 1, 55, 69 (1955).

17. REPORT at 4. This important decision was made for rather than by the Committee, which held no meetings during the first year of its existence and so never debated or voted on the general nature of its aims or program. 
hand, is choice of goal. National policy is evolved by reconciliation of conflicting goals of different interest groups. This calls for a principle of committee selection by interest. Farmers, small business, labor and consumer groups would have to be represented. ${ }^{18}$ Experts would have constituted a minority and might even have been relegated to staff or advisory functions as in the T. N. E. C. and congressional committees. The contrast between T. N. E. C. and the Brownell Committee in this regard is rather graphically illustrated in the role played in each study by the Department of Labor. In the original T. N. E. C. resolution, Labor, and not the Commerce Department, was designated as one of the executive departments to be represented. Conservative forces proposed to substitute Commerce for Labor as an avowedly pro-business gesture. A compromise resulted in both departments being represented on the T. N. E. C. ${ }^{19}$ In the Brownell Committee Secretary of Commerce Weeks was a member; the Secretary of Labor was not.

The inconclusiveness of expertise on matters of national policy is illustrated by the work of our extremely able economist members. They helped to refine concepts and to cancel out some false notions occasionally put forward in the name of economic science, but ultimately they split as decisively as our lawyers. When experts fall out, it is well for the citizen to assume that the controversy has to do with philosophy or political outlook.

\section{The Drive for UNANIMITy}

If it was important that the Attorney General's Committee be representative, at least in the sense that it include experts on both sides of the antitrust controversy, it was equally important that the final report appear as a substantially unanimous judgment of liberals and conservatives. The coupling of these two themes of representativeness and unanimity is nowhere better expressed than in Co-Chairman Oppenheim's words on the occasion of presenting the final report to Attorney General Brownell:

"At this time I emphasize that the Committee membership was selected to reflect a wide range of responsible viewpoints on major issues of antitrust policy. A glance at the list of members makes clear that in this endeavor we certainly have succeeded. In my opinion, perhaps the outstanding contribution of this Report is that these interacting viewpoints have produced a unanimous

18. Compare the composition of the Twentieth Century Fund's Committee on Cartels and Monopoly, supra note 8.

19. LYNCH, op. cit. supra note 1 , at 30 . 
[sic, notwithstanding a general dissent of six members] statement of basic principles of antitrust policy." 20

A conservative majority report, opposed by a dissent, would be regarded, rightly or wrongly, as a partisan or big business recommendation.

Several steps were taken which gave promise of protection against the grave threat to the usefulness of the Report inherent in the possibility that the Committee would be split. (1) A plan of operation was adopted which gave the Co-Chairmen much of the responsibility for the final report. The Committee was divided into Work Groups assigned to particular topics which eventually became chapters in the Report, with the right reserved in the Co-Chairmen to edit the submissions of the Work Groups; and (2) a steady pressure was maintained against expression of individual views, beginning with perfectly reasonable appeals to compromise mere differences of language, but mounting finally to absolute refusal to include, except as condensed fragments distributed through 393 printed pages of the Report, the general dissent in which six members of the Committee joined. ${ }^{21}$

A noteworthy instance of the scope of the "editing" power was the disposition of the proposal to call upon Congress to review and reverse the trend toward substituting restricted entry and rate regulation in fields like motor transportation where competition was appropriate. In the final meeting of the Attorney General's Committee, this matter was debated; a special subcommittee drafted precise language embodying the sense of the proposal, and the draft was approved by a large majority. A week or so after this final Committee meeting, some individual members protested to the Co-Chairmen. As a result, without any further meeting, or vote of the Committee, this considered action of a majority of the entire Committee was abandoned in favor of the following statement:

"Some members feel that, since we have made no factual study of each regulated area, the Committee should refrain from any recommendation for general congressional review of the need for regulation. Others favor a general recommendation to Congress that the trend toward regulation should be checked or even reversed. They emphasize, however, that any such readjustment must make adequate provision to avoid undue hardship to the

20. Dep't of Justice Release, March 31, 1955.

21. The dissent was privately printed. It was reprinted in 1 AnTITRUsT Bull. 37 (1955) and has been incorporated in the printed transcript of hearings held before several congressional committees, including Hearings Before the Subcommittee on Antitrust Law of the House Committee on the Judiciary, 84th Cong., 1st Sess., ser. 3, pt. 1, 247-64 (1955). 
interests affected. Several Committee members favor specifying the motor carrier industry as an example of unnecessary restriction of competition through regulation of entry and minimum rates." 21a

I have no doubt that the Co-Chairmen believed, as one of them said to me, that the Committee majority had not understood the full implications of their vote. Whenever I disagreed with the majority, I tended to have the same feeling. For all I know, the language of the Report does reflect distribution of Committee opinion more accurately than the vote. At any rate, I cite the case only to illustrate the degree of central responsibility assumed.

I hasten to acknowledge that the Work Group organization was not adopted simply as a device for maintaining effective centralized control of the final product. On the contrary, much more obvious considerations must have suggested this form of distributing the work load of the Committee. The field to be covered was vast and intricate. Many members of the Committee were specialists in one or another segment of it. Sixty busy people meeting briefly and infrequently obviously cannot sit as a committee-of-the-whole to draft a report. What, then, was the alternative? One might have been to have a preliminary meeting of the entire Committee to approve a list of crucial issues on which staff personnel or designated consultants would write monographs. Committee leadership could then have submitted to the Committee carefully framed proposals incorporating different points of view and supported by memoranda concisely summarizing the pros and cons. Such a process would have yielded a much shorter report dealing with fewer and more important issues, to which it could be fairly assumed that most committee members had given close consideration. The detail of the underlying staff memoranda could have been preserved for posterity by publishing them for what they were -staff memoranda. That was substantially the way T. N. E. C. operated. In contrast, our Report incorporates what are essentially staff memoranda, as if the sixty of us really could have considered and debated the literally hundreds of interpretations, deprecations, laudations of this, that and the other case or proposition of law or economics tucked away in the text and fine print footnotes of nearly 400 pages of print. $^{22}$ If the other committee members are like me, they are

21a. REPORT at 269.

22. The real "staff memoranda," i.e., the original Work Group reports, and, in some instances, brilliant drafts prepared for the Work Group by juniors in some committee-member's firm, not only remain unpublished, but have been made the subject of a pledge of secrecy to protect the authors against charges either of bias toward their clients or of betraying client's interests. 
still finding in this document interesting propositions of which they have no prior recollection.

Other consequences of the Work Group structure, beside inflating the Report and almost necessitating great central control over the final assembly of separate group reports, are: relatively greater emphasis on specialist's "expertise" at the expense of overall judgment; some tendency to isolate academic criticism from practical dispositions by putting the professors to work on chapters dealing mainly with abstract general principles (presumably their specialty) while practitioners concentrate on, let us say, "remedies"; and an occasional outright contradiction between different chapters of the Report. ${ }^{23}$ If the choice of the Work Group principle has the importance I attribute to it, it is all the more remarkable that this choice was not made by the Committee. In fact the Committee convened for the first time almost a year after it was formed. By this time, of course, the Work Groups had proceeded far along their course.

The persistent pressure for unanimity, previously referred to, deserves further reflection. There was and remains in my mind serious question regarding the duty of individual committee members in such a situation to yield private convictions in order to achieve committee solidarity. There are many group situations in which it is clearly one's duty to do that in order effectively to carry out a common course of action. For example, publication of differences of opinion among the general's staff regarding risks and tactics in a prospective battle would undermine morale. In the political arena, the President can reasonably expect cabinet differences to be reserved for his private ear. These are action groups where voiced dissent would impede group action. I am inclined to think that an advisory group serves the advisee best by indicating precisely how it is divided on substantial issues. If I were admiral and half my staff were strongly in favor of sailing north, the other half just as persistently in favor of sailing west, I should feel quite deceived to be presented with a "unanimous" opinion in favor of a northwesterly course. So it seemed to me that, as advisors to Congress and the Executive, we owed them a fair description of our differing recommendations and the relative support in the Committee for one policy or another. They are, after all, the responsible officers; Congress is the place where compromises are

23. E.g., calling dissolution the "obvious remedy" (REPORT at 33) that should have been applied in the Timken situation (Timken Roller Bearing Co. v. United States, 341 U.S. 593 (1951)) ; and citing Timken in the course of an argument that "judicial reluctance... is firmly grounded on considerations of policy." REPORT at 355. Cf. erroneous statement in my dissenting opinion that "the Timken case stands unchallenged . . . " written in reliance on the latter of these references. The Schwartz Dissent, 1 A'ntitrust Bull. 37, 41 (1955). 
hammered out in the light of our total policy. There are, of course, many statements of divided opinion in the Report. But they are on specific and sometimes quite minor issues. The general effect is of solid support for the Report as a whole, with occasional reservations on some particular. On the overriding and central issue, whether antitrust enforcement in general had gone too far or had fallen short of its goal, whether to sail north or west, the Committee never even took a vote. One had to assemble and count the individual recommendations and draw an inference as to the dominant policy that was finding expression in most of these details. Such a calculation made it clear to me that if "strengthening" the antitrust laws could be said to lie northward on the political compass, this Committee of Navigators had laid out for the Captain a meandering course to the south.

Even on particular proposals, the Report does not truly portray division of opinion. Since most members honestly believed in the importance of achieving unanimity, a kind of bargaining took place. One of the most striking illustrations of this is the tendency of the Report to maintain a semblance of deference to certain crucial decisions inimical to antitrust, like the 1920 Steel case ${ }^{24}$ and Appalachian Coals $^{25}$ of the 30's. In the former a one vote majority of an incomplete Supreme Court (the decision would have gone the other way if the non-participating Justices had voted) refused to dissolve an amalgamation of more than half the steel capacity of the country. In the latter an obvious attempt at collective price-fixing, during an economic crisis which the Government was desperately trying to solve by other price-fixing expedients, was sustained on terms so qualified as to render it legally hazardous for the parties to proceed in reliance on their victory. In my opinion men who knew that these decisions were wrong decided not to express that belief but to be satisfied with the Report's effort to construe the opinions narrowly. They did so in exchange for other members' willingness to compromise the great conservative crusade for a universal "rule of reason" approach to antitrust problems. More than once I was told by committee members who had given years of their lives to enforcing the antitrust laws that, while agreeing with the central thesis of my dissent, they would not join in it. They cherished the hard-won compromises achieved in Work Group debates. They regarded the Report, as whole, as a gratifying job of "holding the line." This was no time to be expecting to make advances. This was an era when our forces could count a stalemate as a victory. I respect these men and their judgments while disagreeing

24. United States v. United States Steel Corp., 251 U.S. 417 (1920).

25. Appalachian Coals, Inc. v. United States, 288 U.S. 344 (1933). 
with them. Their view of the task of the liberals was conditioned by politics and the times, just as the administration's hypothesis that the antitrust laws had gone too far was a product of the era. With antitrust on the defensive, it would indeed be an achievement merely to stem the attack. Had it been done? Or had the majority, its numbers unnaturally swollen with real believers in hard competition, sanctioned a quiet piecemeal retreat?

\section{Committee Research-Fact Finding or Policy?}

A notable feature of investigations conducted by congressional committees and famous special commissions of the past has been the volume of new facts brought out-either in public hearings or published staff monographs. The investigation which led to enactment of the Public Utility Act of 1935 produced 100 volumes of hearings and reports, describing the actual operation of the business being investigated. The T. N. E. C. hearings likewise were devoted largely to testimony about practices and structure of industry. Among the 43 monographs of T. N. E. C. are volumes describing the organization of trade in steel, insurance, petroleum and moving pictures, as well as authoritative summaries of antitrust law and economics. Some of the printed monographs were submissions by the industry commenting on and refuting staff writings. The 431 page Final Report of the Executive Secretary to the T. N. E. C. ${ }^{26}$ summarizes the material in the hearings and monographs. Excerpts from its Table of Contents which appear as Appendix $A$ to this Article show the extraordinary range and detail of factual inquiry upon which T. N. E. C.'s recommendations were based. ${ }^{27}$ The Brownell Committee leaves no such legacy:

"We stress that our aim is not to add to the storehouse of statistical data or to survey the economic effects of antitrust applications to specific industries. These tasks have in part already been undertaken by others. Undoubtedly, they will again be attempted in testing this Report's specific recommendations or in some other connection. Instead, this Committee's primary task is to mark out as clearly as possible the path antitrust has traveled and what it augurs for the future. In this process, we build, of course, on the collective experience of prior efforts . . . ."28

Not only did it fail to produce facts; it gave practically no consideration to the massive factual investigations which preceded it. One may

26. Exec. SeC'y of the T.N.E.C., Final Report to the T.N.E.C. on the CoNCENTRation of ECONOMIC POWER IN THE UNTTED States (1941).

27. See pp. 170-71 infra.

28. REPORT at 4. 
search the hundreds of footnotes of the Report in vain for references to the published hearings and reports of the congressional committees which have operated almost continuously in this field during and since World War II. As for T. N. E. C. it might as well never have existed, so far as the Report is concerned. The impossibly voluminous factual data of previous investigations were never digested for us by staff memoranda, and I recall very few references to any of this material in our committee debates. The statement that we built "on the collective experience of prior efforts" goes far beyond the realities of our operation.

And yet-scholarship and research of a very high order went into the making of the Brownell Committee Report. The magnificent talents available in the Committee were devoted to a very special kind of research, in the words of the Report quoted above: ". . . to mark out as clearly as possible the path antitrust has traveled . . ."-i.e., legal research-without surveying "economic effects" of past decisions on particular industries. "[W] hat it augurs for the future" is apparently to be inferred by projecting forward the policy line of the past. That is precisely the kind of research and forecasting that every skilled practicing lawyer does when attempting to predict what a court or administrative agency will decide under existing laws and precedents. It has very little to do with how the law should be changed; and that, after all, was what this Committee had been asked. To tell whether a law should be changed one must know how it is working, i.e., precisely those economic effects on particular industries which the draftsmen of the Report decline to "survey." Thus it came about that our Committee succeeded in writing a report on the antitrust laws without finding it necessary to consider whether the economic and political effects of organizations like General Motors or United States Steel call for stronger measures than now exist to combat concentration. On the other hand, when the Committee was disposed to recommend a change, e.g., relaxation of the law against price discrimination, or repeal of the "fair trade" laws, it did so quite without examination of the actual consequences of past policies on the industries affected. One finds only references to the theoretical likelihood that strict antidiscrimination measures will encourage price rigidity ${ }^{29}$ or to the logical

29. Cf. dissent of Professor Alfred E. Kahn. REPORT at 185. See also the testimony of Professor Joel B. Dirlam and Dr. Irwin M. Stelzer, among others, Hearings Before the Select House Committee on Small Business, 84th Cong., 1st Sess. (mimeo. transcript 1955), pointing out pro-competitive consequences of the Robinson-Patman Act. Dr. Stelzer reviews in some detail the actual consequences of orders against price discrimination in corn syrup and cement, pointing out, for example, that in corn syrup "another effect of the glucose decisions was to terminate pricing practices which had so adversely affected small candy manufacturers 
inconsistency of resale price maintenance and normal Sherman Act standards. There is not a word, for example, of the documented finding of the Federal Trade Commission that resale price maintenance costs the consumer money, ${ }^{30}$ nor, for that matter, any rejection of the proposition, strongly urged upon our Committee in certain trade association briefs, that resale price maintenance preserves small business without great cost to the consumer. Much as I agree with the majority position against resale price maintenance, I can hardly expect Congress to accept this recommendation on the doctrinal grounds advanced by the Report.

It seems clear that the Brownell Committee's policy preferences are not supported by its research or even by systematic use of the factual researches of others.

\section{ConcLusion}

The ultimate impact of the Report remains to be seen. Congressional committees, now in Democratic control, have naturally given it rough treatment. So far as enacted legislation is concerned, Congress raised the maximum criminal fine to $\$ 50,000$ even before the Report came out with its recommended increase to $\$ 10,000$ (not enough even to compensate for dollar inflation since 1890). The United States has been declared eligible to recover damages which it suffers in consequence of antitrust violations, thus giving force to one of the few pro-enforcement recommendations of the Report. A uniform statute of limitations on private antitrust suits has been enacted, coupling a long-recognized need for uniformity with some novel restrictions on the period for which damages are recoverable even if the suit is filed in time. The conservative recommendations of the Report have a better chance of infiltrating judicial interpretation of the $\mathrm{law}^{31}$ and especially administration by the executive agencies. Recent conserva-

that many of them had been forced to move to Chicago in order to survive. One corn products firm, for example, had maintained a substantial volume of business in Eastern markets by charging customers there a lower net price than was simultaneously being paid by its Western buyers. Here, then, was a perfect example of an instance in which discriminatory pricing seemed to be necessary if any customers were to pay lower prices. Yet, when it became impossible for this company to charge a higher price to its Western than its Eastern customers, it did not simply withdraw from the less remunerative market. Instead, it cut its base price so that it could reach the East Coast on a competitive basis, even though this also meant a price cut for its Western buyers. The abolition of price discrimination in this instance, then, led to a uniformly lower price to all customers." (Emphasis added.)

30. FTC, Report on Resale Price Maintenance (1945).

31. At the suggestion of the Attorney General, the Administrator of the Federal Courts sent a copy of the Report to every federal judge in the United States. Testimony of Co-Chairman Oppenheim in Hearings Before the Select Honse Committee on Small Business, 84th Cong., 1st Sess. (1955), according to release of Congressman Patman dated Nov. 10, 1955. 
tive tendencies in the Federal Trade Commission, for example, received strong endorsement in the Report and may harden into established administrative practice. ${ }^{32}$ On the other hand, the United States Court of Appeals for the Third Circuit has just held that to condition a patent license on the licensee's agreement to refrain from dealing in competitive goods is an abuse of patent. Taking cognizance of the Report's animadversions on a similar previous holding as ". . . mere theoretical analysis without consideration of actual commercial effect. . . ." 33 Judge Biggs returns the compliment with the observation that "the parties, their dealers, distributors, and indeed, their customers, are not living in a strange, non-commercial world where exclusive agreements are found under Christmas trees." 34 Did Judge Biggs mean to imply that the Brownell Committee lived in such a world?

The most significant feature of the Report from the policy standpoint is that, in spite of all, it did not succumb completely to the "rule of reason" philosophy. In principle, the per se doctrine survived; the distinction between Sherman and Clayton Act standards of legality was recognized, however frequently compromised; neither foreign trade nor any other special field was handed over to private regulation in the name of "business necessities." My principal criticism and suggestions, as submitted in outline to the Antitrust (Celler) Subcommittee of the House Judiciary Committee are set forth in Appendix B to this Article. ${ }^{35}$

At the very least the Report has provided an excellent textbook for students of antitrust, a good starting point for any lawyer who has a problem in this field. For all of us it furnishes an occasion for rethinking the relationship of law, scholarship and politics.

32. See Note, The "New" Federal Trade Conmission and Enforcentent of the Autitrust Lawe, 65 Y ALE L.J. 34 (1955).

33. REPORT at 251.

34. Russell Co. v. Consumers Insulation Co., 226 F.2d 373, 376 (3d Cir. 1955).

35. See pp. 172-75 infra. 


\section{APPENDIX A}

Excerpts from the Table of Contents of the Final Report of the Executive Secretary to the Temporary National ECONOMIC CoMMITTEE*

\section{Chapter II}

Concentration of production $\ldots \ldots \ldots \ldots \ldots \ldots \ldots \ldots \ldots \ldots \ldots$

Trends in size and concentration in manufacturing establishments

Central-office control in manufacturing.$\ldots \ldots \ldots \ldots \ldots \ldots$

Size and diversity of operations of central-office companies ....

Areas and measures of the concentration of central-office control

Central-office establishments versus independent establishments

The role of the largest manufacturing companies ............

Product concentration.$\ldots \ldots \ldots \ldots \ldots \ldots \ldots \ldots \ldots \ldots \ldots$.

The concentration of production in manufacturing ...........

Distribution of the number and value of products by con-

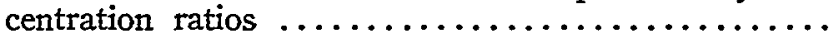

Relation of concentration to number of companies .........

The role of the production of the leader ..............

Frequency with which leaders appeared...$\ldots \ldots \ldots \ldots$

Relation of concentration to various product characteristics

The concentration pattern in 1935 and in 1937 .........

The concentration of production in mining $. . . \ldots \ldots \ldots \ldots . . .$.

The product structures of the largest fifty manufacturing

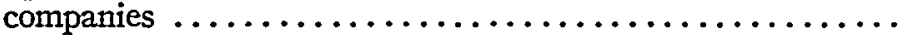

The extent of the operations of the largest fifty manufacturing companies..$\ldots \ldots \ldots \ldots \ldots \ldots \ldots \ldots \ldots$

The importance to the individual company of each product manufactured $\ldots \ldots \ldots \ldots \ldots \ldots \ldots \ldots \ldots \ldots$

Proportion of the total United States output of individual products accounted for by each company ............

Relation between the importance of each product to each company and the importance of each product in the

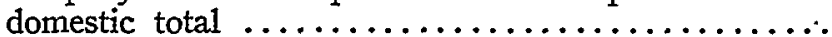

The role of the largest fifty manufacturing companies as

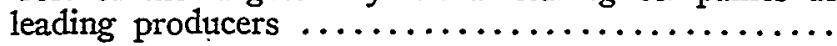

\section{Chapter IV}

Controlled production and sales-trade associations and cartels ....

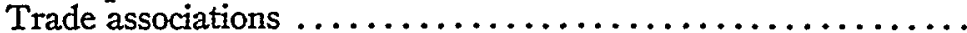

Association activities ........................ 85

Limitation of competition through trade associations ...... 88

Control of prices through trade associations .......... 89

Allocation of markets and customers through trade associations

Allocation of production and sales through trade associations

Trade association boycotts ......................

Local associations $\ldots \ldots \ldots \ldots \ldots \ldots \ldots \ldots \ldots \ldots \ldots, 93$

Cartels

Building construction .................... 94

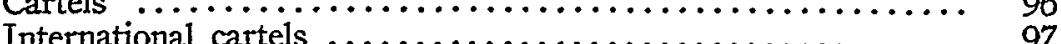

* Exec. Seciy of the T.N.E.C., Finar Report to the T.N.E.C. on the Concentration of Economic Power in the UnIted States v-vi, viii-ix (1941). 
Cartels in the American market .................. 98

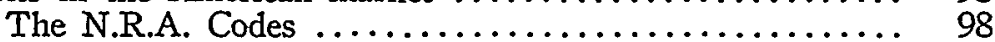

The aftermath of the N.R.A. ................... 100

Export associations

\section{* * * * * \\ Chapter XIV}

Small business ................................. 297

Number of small enterprises $\ldots \ldots \ldots \ldots \ldots \ldots \ldots \ldots \ldots \ldots \ldots, 297$

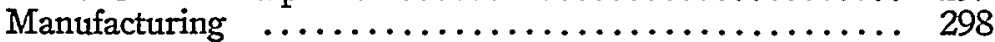

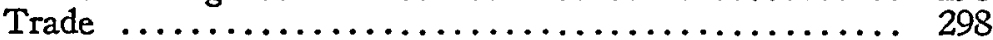

Service ................................. 299

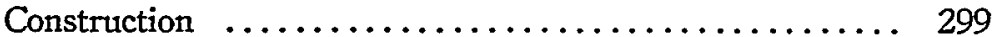

Mining and quarrying ....................... 299

Factors affecting numbers in various groups ............ 299

Economic problems .......................... 300

Effects of structural changes in the economy ............. 300

Economic position $. . \ldots \ldots \ldots \ldots \ldots \ldots \ldots \ldots \ldots \ldots \ldots, 301$

Earnings $\ldots \ldots \ldots \ldots \ldots \ldots \ldots \ldots \ldots \ldots \ldots \ldots \ldots, \quad 302$

Debt $\ldots \ldots \ldots \ldots \ldots \ldots \ldots \ldots \ldots \ldots \ldots \ldots \ldots \ldots, 303$

Working capital ......................... 303

Equity $\ldots \ldots \ldots \ldots \ldots \ldots \ldots \ldots \ldots \ldots \ldots \ldots \ldots \ldots \ldots \ldots, 304$

Sales ................................ 304

Credit and capital problems ..................... 305

The commercial bank as a source of credit ............ 305

Trade credit .............................. 306

Accounts financing companies .................. 307

Other credit sources $. . \ldots \ldots \ldots \ldots \ldots \ldots \ldots \ldots \ldots \ldots \ldots, 307$

Sources of capital $\ldots \ldots \ldots \ldots \ldots \ldots \ldots \ldots \ldots \ldots \ldots \ldots \ldots, 308$

Other factors in mortality $\ldots \ldots \ldots \ldots \ldots \ldots \ldots \ldots \ldots \ldots, 308$

Aids to small business ........................... 309

General Federal and State regulation ............... 309

Other legislative aids $\ldots \ldots \ldots \ldots \ldots \ldots \ldots \ldots \ldots \ldots \ldots \ldots, 311$

Government financial aids $\ldots \ldots \ldots \ldots \ldots \ldots \ldots \ldots \ldots \ldots, 312$

Suggested aids $\ldots \ldots \ldots \ldots \ldots \ldots \ldots \ldots \ldots \ldots \ldots \ldots \ldots, 313$

Equity capital proposals $\ldots \ldots \ldots \ldots \ldots \ldots \ldots \ldots \ldots \ldots \ldots, 314$

Direct loan proposals $. . \ldots \ldots \ldots \ldots \ldots \ldots \ldots \ldots \ldots \ldots \ldots \ldots, 314$

Insurance proposals $\ldots \ldots \ldots \ldots \ldots \ldots \ldots \ldots \ldots \ldots \ldots \ldots, 315$

Mixed proposals $\ldots \ldots \ldots \ldots \ldots \ldots \ldots \ldots \ldots \ldots \ldots \ldots \ldots, 316$

Increasing national income $\ldots \ldots \ldots \ldots \ldots \ldots \ldots \ldots \ldots, 317$

Chapter XV

Consumers ..................................... 319

Consumer enterprise $\ldots \ldots \ldots \ldots \ldots \ldots \ldots \ldots \ldots \ldots \ldots \ldots, 319$

The consumer interest $\ldots \ldots \ldots \ldots \ldots \ldots \ldots \ldots \ldots \ldots \ldots \ldots, 320$

Impact of concentration of power upon consumers ......... 322

Price control ............................. 322

Control of progress $\ldots \ldots \ldots \ldots \ldots \ldots \ldots \ldots \ldots \ldots \ldots, 323$

Control of choice $\ldots \ldots \ldots \ldots \ldots \ldots \ldots \ldots \ldots \ldots \ldots \ldots, 324$

Government aid for consumers $\ldots \ldots \ldots \ldots \ldots \ldots \ldots \ldots \ldots \ldots, 328$

Types of Government action ....................... 330

Government services to consumers $\ldots \ldots \ldots \ldots \ldots \ldots \ldots \ldots, 332$

Promotional $\ldots \ldots \ldots \ldots \ldots \ldots \ldots \ldots \ldots \ldots \ldots \ldots \ldots, 332$

Protective $\ldots \ldots \ldots \ldots \ldots \ldots \ldots \ldots \ldots \ldots \ldots \ldots \ldots \ldots, 332$

Financial $\ldots \ldots \ldots \ldots \ldots \ldots \ldots \ldots \ldots \ldots \ldots \ldots \ldots, 3 \overline{3} 5$

Shortcomings in consumer services $\ldots \ldots \ldots \ldots \ldots \ldots \ldots \ldots, 335$ 


\section{APPENDIX B}

Outline-Summary of Testimony of Prof. Louis B. Schwartz of the Law School of the University of Pennsylvania **

\section{On the Report of the Attorney General's National Committee to Study} the Antitrust Laws:

A. General Appraisal. Although it contains a few recommendations favorable to free and fair competition, the overwhelming majority of its proposals in the field of legislation, interpretation and administration tend to weaken the antitrust laws. The Committee failed to carry out its mission to "strengthen" the antitrust laws primarily because it decided to concentrate on legal analysis of existing statutes and decisions. Thus it managed to avoid facing major issues of policy such as whether a pattern of industry domination by two or three firms requires fundamental change in the statutory scheme that permits this conditon to continue. Somewhat inconsistently, the Committee did give effect to its notions of policy in making numerous proposals whose combined effect is to relax existing law and impede its enforcement.

B. Major Deficiencies. Among the major errors and deficiencies of the Report are the following:

1. It makes no effective proposals to prevent further expansion of dominant firms by merger.

2. It fails to provide for breaking up existing superconcentrations of control in fields like steel, aluminum, motor cars.

3. It disapproves breaking up monopolistic agglomerations, except as a last resort, even when they have been convicted of abusing their power.

4. It approves industry-dominating patent pools, if they exercise their control "reasonably."

5. It approves price-fixing under patents and restrictive licensing, without regard to whether the licensor is a dominant firm.

6. It would exclude compulsory royalty-free licensing as an available form of relief in patent-abuse cases.

7. It encourages exclusive dealing, by making it necessary to show "actual foreclosure" from the market-a rule which, if appropriate in Sherman Act cases, is certainly inconsistent with the Clayton Act purpose to forbid restrictive practices that are potentially rather than actually impairing competition.

8. It undermines the Robinson-Patman Act's effort to prevent big sellers from discriminating unjustifiably among their customers, and to prevent big buyers from coercing price concessions not related to the lower cost of doing business with them.

9. It proposes to impair existing right of the antitrust victim to recover mandatory treble damages and to restrict the period for which damages may be recovered. It fails to deal affirmatively with the existing situation under which antitrust victims are in most cases practically unable to recover even compensatory damages because consent decrees under Section 5 of the Clayton Act do not make a prima facie case of violation. 
10. It fails, except in the one instance of Fair Trade, to do anything about the vast sectors of our economy that have been withdrawn from free competition, sometimes by legislative restriction on entry, as in motor and air transportation, sometimes by express exemption, e.g., for collective rate-making by common carriers and casualty insurers, sometimes by judicial interpretations like the "primary jurisdiction" rule.

11. The Report does not reflect any awareness that antitrust law has more than economic significance in American life. Many Americans believe that economic power must be kept reasonably dispersed in order to keep business from dominating government itself. Others believe that a society of vigorously independent individuals can exist only where property ownership and entrepreneurial responsibility are widely distributed.

12. The Report contains internal contradictions resulting from different authorship of various chapters, and does not accurately present the variety of opinions among the Committee members.

13. The Report says nothing about adequate appropriations for effective antitrust enforcement.

C. The Opportunity Presented by the Report. Although the Attorney General's Committee misfired, the very fact that such a Committee was convened and that it failed focuses on the need for positive measures in this area and gives the legislative branch of government an opportunity to "modernize and strengthen" the antitrust laws.

\section{A Progran for Legislative Action.}

\section{A. INVESTigation.}

1. Further generalized investigation of antitrust problems would be of doubtful utility. More immediately useful would be a well-financed analysis-digest-index of the voluminous information accumulated in all the post-World War II Congressional hearings. In addition the following specific topics might be fruitfully explored, not necessarily by public hearing.

2. A legislative committee might conduct pilot studies of a few of the very largest industrial giants with the specific objective of drawing up tentative reorganization plans that would limit these enterprises to reasonably related activities on a scale justified by technological requirements. On the basis of several such studies Congress would be better prepared to enact general legislation, patterned on Section 11 of the Public Utility Holding Company Act of 1935.

3. A study might be made of the extent of uncompensated injury to competitors and the public in several of the more important antitrust cases of the recent past, especially where consent decrees have been entered.

4. There should be a study of the number of cases of price-fixing and other clear violations of the Sherman. Act which have been disposed of by FTC cease and desist order or by consent decree, when criminal prosecution would have been appropriate under the announced policies of the Department of Justice. 
5. There should be compiled a list of the restraint of trade cases brought against leading firms, to reveal which if any of them are habitual violators.

6. The actual operation of some leading patent pools might be closely examined.

\section{B. Legislation Indicated as Probably Desirable.}

1. Prohibit dominant companies from expanding by merger, without advance approval based upon a showing of technological necessity.

2. Provide a means for breaking up existing superconcentrations, organizations like General Motors and United States Steel. If American Motors is large enough to survive, General Motors must be bigger than technological necessity requires. If Bethlehem and Youngstown are big enough, United States Steel must be too big.

3. Enact a legislative declaration that competition (free enterprise, untrammeled business choice, etc.) is preferable to private (or public) regulation, except where Congress has clearly directed otherwise, and that agencies administering statutes which authorize dispensation from the rule of competition "in the public interest" or "to promote the national transportation policy" shall not grant such dispensation unless available alternative methods of promoting the alleged public policy are shown to be less practicable. It should not be enough to show that a merger inconsistent with the antitrust laws is "consistent" with the public interest.

4. Declare legislatively that the restrictive practices specifically named in the Clayton Act are unlawful without inquiry as to their competitive effects in a particular situation, when engaged in by dominant firms.

5. Prohibit restrictive licensing of patents by dominant patentees and the combination of dominant companies in patent pools.

6. Amend Section 5 of the Clayton Act to make it discretionary with the court whether a consent decree shall be available to help private plaintiffs make out a prima facie case; in the alternative, provide a procedure for compensating all antitrust victims upon the successful conclusion of any government case.

7. Amend the Motor Carrier Act to eliminate control of entry and rates, as well as exemptions from the antitrust laws, direct the C.A.B. to establish conditions which will make possible new entry into trunk line air transportation.

8. Repeal the Reed-Bullwinkle authorization of collective rate making by railroads, and the McCarran Act exempting certain insurance operations from the antitrust laws.

9. Repeal the McGuire Act authorizing resale price control in interstate commerce.

10. Raise the maximum fine for violations of the Sherman Act to at least $\$ 50,000$.

11. Permit the United States to recover as a party injured by antitrust violations. 
12. Create a permanent Free Enterprise Commission to take over the antimonopoly functions of the Federal Trade Commission and to make antitrust investigations, reporting to the Department of Justice which would conduct litigation before the courts. Among the powers and responsibilities of the Free Enterprise Commission would be the following:

(a) Power by regulation to define and prohibit anticompetitive practices.

(b) Power by regulation or order to prevent integration not justified by production or distribution economies, and to require advance approval for certain classes of such transactions.

(c) Power to compel the reorganization of excessively large enterprises into units conforming with the standard of paragraph (b).

(d) Power to make exemption under standards defined by statute.

(e) Authority to appear before any government agency, including Congressional Committees, to present testimony or argument as to the implications for free enterprise of the matter before the agency.

(f) A duty to report annually on the state of free enterprise in the country and to propose legislation for the further protection of free enterprise. 